\title{
Creative Village Planning in An Effort to Support the Realization of Creative City
}

\author{
Khikmatul Islah $^{1}$, Ivan Budi Susetyo ${ }^{2}$, Aryo Santiko ${ }^{3}$ \\ ${ }^{12}$ Institut Ilmu Sosial dan Manajemen Stiami, Jakarta, Indonesia \\ Correspondent: izlahzone@gmail.com
}

\begin{abstract}
Received : August 08, 2021
Accepted : August 25, 2021

Published : October 31, 2021
\end{abstract}

Citation: Islah, K., Susetyo, I.B., Santiko, A. (2021). Creative Village Planning in An Effort to Support the Realization of Creative City. Ilomata International Journal of Social Science, 2(4), 267-274.

https://doi.org/10.52728/ijss.v2i4.375

\begin{abstract}
Population growth that continues to increase without being balanced with the extent of urban land causes an uncomfortable environment for all its society or communities. People need a change to have a better life. Something new is required to solve this problem. One of solution is to create a Creative Village (Kelurahan Kreative), also as a form of support in realizing the Creative City. This study uses qualitative research with literature study in data collection. The results show that this Creative Village can run with support from various parties; government, society and the private sector. The collaboration of various parties will facilitate in realizing creative villages, which can be done by empowering the younger generation who are members of Karang Taruna (youth group). This young generation will move and develop the Creative Village. To support them, at first these young men will get various training as provisions. The use of technology is also important in efforts to realize Creative Village that will further support the creation of Creative City.
\end{abstract}

Keywords: Creative Village, Creative City, Realization

\section{INTRODUCTION}

The population growth as a result of urbanization and the limited land area in urban areas led to increasing number of homes, both legal and illegal. For dense and slum areas or slum village, in Indonesia, this area called slum area or kampung kumuh. This is one of the causes of the problems, in addition, comes economic problems. Slums are a problem faced by almost all big cities in Indonesia, even big cities in other developing countries. The study of slum settlements generally includes three aspects, namely, first, its physical condition. These physical conditions can be seen, among others, from the very tight condition of the buildings with low construction quality, unpatterned and unpaved road networks, non-functioning general sanitation and drainage and waste that has not been managed properly. Second, the socio-economic and cultural conditions of the communities living in these settlements. The socio-economic conditions of the people living in slum areas include low income levels, loose social norms, a culture of poverty that characterizes their lives, which among other things can be seen from apathetic attitudes and behavior. Third, the impact of these two conditions. These conditions often also result in poor health conditions, sources of pollution, sources of disease spread and 
deviant behavior, which have an impact on their overall life.(Alam et al., 2019; $\underline{\text { S. Aziz et al., }}$ $\underline{2021)}$

Slum areas are considered a city disease that must be overcome. Population growth is the main factor that drives the growth of settlements. While the socio-economic conditions of the community and the ability of city managers will determine the quality of the realized settlements. Slums are a product of population growth in poverty and the lack of government to control growth and provide adequate urban services. (Adnan et al., 2018; Das et al., 2021)

The global population in cities is expected to reach $60 \%$ by 2030 , and $70 \%$ by 2050 . The number of cities with a population of more than 1 million people will reach 450 cities, with more than 20 cities as megacities, with a population exceeding 10 million. The condition of cities in Indonesia that is developing and functioning as activity centers invites residents of the surrounding area to come looking for jobs and a better life. Those who migrate to urban areas are relatively increasing from year to year. They come from different socio-economic backgrounds and some of them come without a clear purpose.(Michiani \& Asano, 2019; Nyenje et al., 2014)

On the other hand, the city is not ready with an urban system plan to accommodate the development of urban activities in the city spatial planning system with various aspects and implications including accepting, regulating and utilizing migrants. As a result, activities are very heterogeneous and not in the unified system of planned urban activities, which results in pockets of activities that do not support each other, including the emergence of settlements that develop outside the plan so that slum settlements are formed.(T. A. Aziz \& Shawket, 2011; Izutsu et al., $\underline{2006})$

The limited funds owned by the government for urban planning and management in dealing with the population problems mentioned above have also caused housing and settlement facilities to be limited and expensive to finance. In urban areas, the people whose needs for housing and settlement facilities are not adequately met are those who are classified as lowincome and or in other words the poor. When a person is faced with a problem regarding the expenditures that must be made to meet the needs of his life, eating, dressing, and medical treatment for health, the first thing that is sacrificed is the expenditure for his house and residence. regarded as a city disease that must be overcome. Population growth is the main factor that drives the growth of settlements. While the socio-economic conditions of the community and the ability of city managers will determine the quality of the realized settlements. Slums are a product of population growth in poverty and the lack of government to control growth and provide adequate urban services. (Khalifa, 2011; Rivera-Padilla, 2021)

The global population in cities is expected to reach $60 \%$ by 2030 , and $70 \%$ by 2050 . The number of cities with a population of more than 1 million people will reach 450 cities, with more than 20 cities as megacities, with a population exceeding 10 million. The condition of cities in Indonesia that is developing and functioning as activity centers invites residents of the surrounding area to come looking for jobs and a better life. Those who migrate to urban areas are relatively increasing from year to year. They come from different socio-economic backgrounds and some of them come without a clear purpose.(Klein \& Anderegg, 2021; Yang et al., 2021)

On the other hand, the city is not ready with an urban system plan to accommodate the development of urban activities in the city spatial planning system with various aspects and implications including accepting, regulating and utilizing migrants. As a result, activities are very 
heterogeneous and not in the unified system of planned urban activities, which results in pockets of activities that do not support each other, including the emergence of settlements that develop outside the plan so that slum settlements are formed (Murray-Tortarolo \& Jaramillo, 2020).

The limited funds owned by the government for urban planning and management in dealing with the population problems mentioned above have also caused housing and settlement facilities to be limited and expensive to finance. In urban areas, the people whose needs for housing and settlement facilities are not adequately met are those who are classified as lowincome and or in other words the poor. When a person is faced with a problem regarding the expenses that must be made to meet the needs of his life, eating, dressing, and medical treatment for health, the first thing that is sacrificed is the expenditure for his house and residence.

For example, various efforts were made by the DKI Jakarta Government, to overcome this problem in the capital of Indonesia. This effort had been carried out since the administration of Governor Ali Sadikin in 1967-1979 with the Mohammad Husni Thamrin Project (MHT), known as kampung improvement program, that was a program about improvement of village with the aim that the slums area in Jakarta would be beautiful, at least worthy to be inhabited. The program began by improving roads, adding MCK or public rest room facilities, Puskesmas or health centers, garbage tubs or bins and village security facilities.

Regarding to population density, new problems arise related to residential and the economy. This problem belongs to the community, which is certainly related to his life in a city. The hope of a good life in the residential of a city becomes a dream of all residents.

Every society or community has an expectation on the city that they live in. Ideally, indicators of dream city of Indonesia are: city that is environmentally friendly, having green open spaces, adequate facilities, infrastructure and transportation, cities that have concepts, comfortable and safe situation, creative arts and culture, adequate in economic and an ideal government. An ideal government would lead to many positive things, and would create creative spaces, civilized works of art and culture, good in economics.

In an effort to meet the expectations of the society/communities, special strategies are required. Special strategies to improve the worthiness of residential environments and the economic sustainability of the population are needed in order to achieve the city's orderly flagship area for the community. One of the required strategies for this is creativity. The creativity can be developed starting from the level of the urban village or Kelurahan, namely creative villages, to realize the Creative City.

\section{METHOD}

The type of research used in this study is qualitative. According to Sugiyono, Qualitative research method can be a resource person (informant), event (activities), places (location), various photograph object and recording as well as document and archives. (Sugiyono, 2017)

This research uses literature study to collect data. According to Creswell (2008), literature study is a step of pre-research for every research including R\&D. Literature review is a written summary of journal acticles, books and other documents that describes the past and current state of 
informational; organize literature into topics; and documents a need for a proposed study. (Prasetyo, 2008)

The analysis of the this research based on the understanding of the planning that refer to Harold Koontz dan Cyril O'Donnel, "planning is function of a manager which involves the selection from alternatives of objectives, policies, procedures, and programs". (Fitriani, 2019).

\section{RESULT AND DISCUSSION}

UCCN (UNESCO Creative Cities Network) or commonly called the Creative City is currently vociferously encouraged by UNESCO. This is a program of the SDGs (Sustainable Development Goals), especially with regard to sustainable cities. This program aims to make culture an integral part of development, especially in urban areas. This idea arises from urban studies that identify the importance of creative communities to play a role in urban development, such as Manuel Castells (1982, 2000, 2010, 2016), Richard Florida (2004 dan 2006), Greffe (2011) and many more. (Ulumuddin et al., 2020)

According to data from the Ministry of Tourism and Creative Economy, creative districts / cities are districts / cities that choose one or more subsectors of the creative economy as the economic backbone of their communities, and strive for the activation of the required ecosystem together with the four actors academics, business, community, government, with media support, thus improving welfare through increased labor uptake, Regional GDP donation and encouraging increased exports. (Sobandi et al., 2018)

1. Tujuan

To improve the environmental conditions, the main key is to change the mindset and behavior of citizens. One of the main motivating factors (motivation) for creating creative strategies in the process of forming creative villages is the needs of the community. For physical needs (survival), the need to fulfil the basic needs such as food to eat, sleep, rest, and do other activities with the realization of residential space (home) that facilitates biological needs. In addition, there are social needs and security needs that can be fulfilled easily. After fulfilling the sense of security, there will be the next level of need, namely a sense of belonging to each other.

Nevertheless, if the environmental conditions are bad, it will cause the residents to be reluctant to leave their homes and stay at home whole day. As the result many resident go out of the village to look for public spaces with better quality. Consequently, there is no social interaction on the communities so that the spirit of place will disappear and the need for mutual belonging cannot be fulfilled.(Sugianti \& Ekomadyo, 2016)

The existence of creative strategies or creative ideas is a solution to problems that are present at the insistence of basic human needs. In the formation of Creative Village, the initial conditions of the settlement environment that do not match expectations become a background that motivates citizens to take action in the form of creative ideas or strategies as a solution to environmental problems. (Chairunnisa, 2012)

2. Policy

For example, in DKI Jakarta, based on The Governor's Decree No. 224 of 2015 dated February 6, 2015, there is the Establishment of a Working Group on Acceleration of 5 Tertib Jakarta or 5 Orderly Jakarta, consists of orderly residences, orderly waste Disposal, orderly Street Vendors, orderly Traffic and orderly protest or Demo aimed at accelerating 
development related to the community life in the capital region. (Governor's Decree No. 224 of 2015 Dated February 6, 2015, 2015)

Strengthening the support system can be done by developing an overall Environmental representative followed by the provision of creative activity base space such as Garbage Banks and Waste Recycling Craft Galleries. The success of the creative strategy will be defined by obtaining the various environmental awards. This proves that the needs of appreciation and self-esteem of the community have been met. Residents who begin to have a sense of owning their own residence, need recognition (self-actualization) so that residents continue to innovate to improve the quality of the residential environment. The results of the evaluation of creative activities indicate that there is an increase in the physical quality of the environment and the economy of the residents which also improves the quality of life of the community. Innovations made by residents occur continuously. This shows that the community has succeeded in fulfilling their needs to the highest stage, namely the need for self-actualization. (Wardhani et al., 2016)

3. Procedure

There are three important aspects that need to be considered in the concept of Creative City to make it happened, including the growth of the creative economy, the maintenance of creative classes (creative groups or individuals) and the provision of an environment that conducive to the development of creativity. The creative economy can improve well-being and create jobs. Creative classes have a role in developing the creative economy. While the creative environment will be related to the psychic and physical environment, each has a role in supporting the realization of the Creative City. (Manisyah, 2009)

To realize these three important aspects, it is required to have a collaboration between smart living, smart society, smart environment, smart people, smart governance, smart branding, and smart economy, it will form a smart concept to build a village in an effort to realize kelurahan kreatif or creative villages.

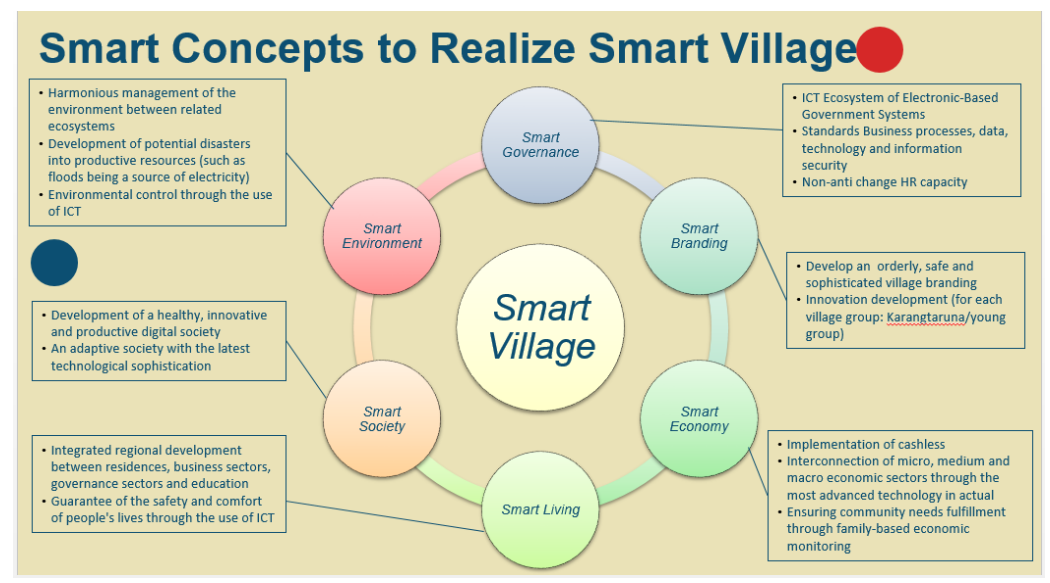

Figure 1. Smart Concept to Realize Smart Village

4. Program

According to Maslow (1954), basically humans have basic instincts that can motivate to fulfill their needs. It is driven by deficiency motivation which aims to reduce the problem of human tension due to various deficiencies and motivation to grow (growth motivation). If humans feel enough on one need, then there will be motivation that triggers humans to make efforts to the next level. (Sugianti \& Ekomadyo, 2016) 
In general, the formation of creative villages is to turn a village that was originally rundown into a tourist village to improve and improve the quality of life. In the formation and development of this tourist village there are several important things, namely the active role of the actors (stakeholders). These actors can be categorized into three parties/actor: the main actor, the supporting actor, and key of interest actor. The main actor is the villagers as recipients of both positive or negative impacts of a creative activity. Furthermore, the supporting actor is the perpetrator who acts as an intermediary in helping the process of delivering activities. They can be classified as funders, implementers, supervisors, and advocacy organizations such as government organizations, Non-Government Organization (NGOs), and private parties. While key of interest actors are actors who have strong or important influence, such as the Government and donors. (Wardhani et al., 2016)

In this research, the discussion of Kelurahan Kreatif or Creative Village is a form of creative village as a form of support for the realization of the Creative City. In accordance with the concept of creative villages, creative villages will be formed based on the implementation of creative villages. This creative village will be a program in every city that wants to realize a Creative City. One of the communities that can be mobilized is young people

This young generation will be a target that will encourage and develop creative villages. These young can be obtained from member of Karang Taruna or Youth Group in the village/Kelurahan.

Figure 2 below is the organization structure of Karang Taruna according to Permensos 25/2019 on Karang Taruna:

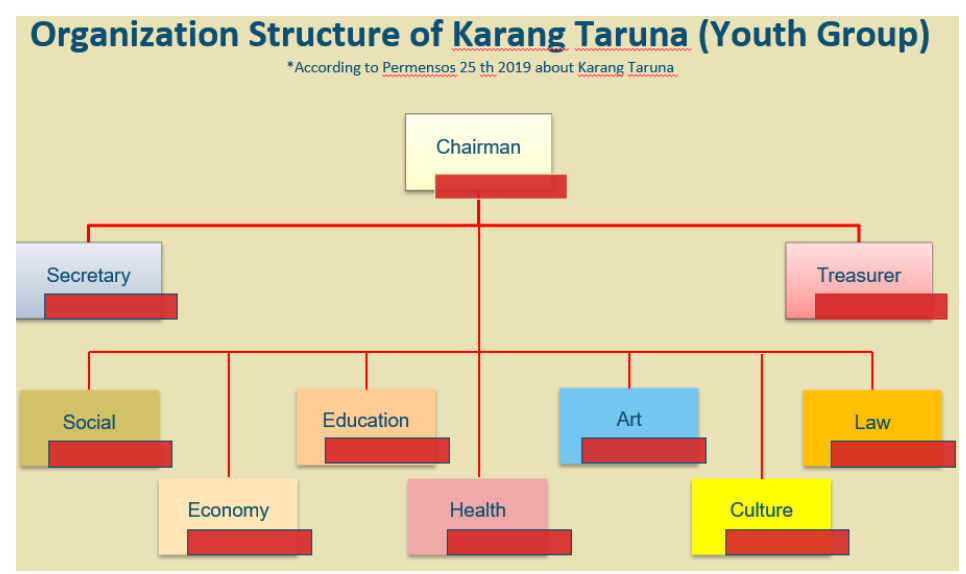

Figure 2. Organization Structure of Karang Taruna (Youth Group)

The program that must be carried out is training for administrators and members of Karang Taruna who are ready to support the realization of the Creative Village. Support from various parties is needed in this training program in order to support the realization of a Creative Village towards a Creative City.

For example, the concept of Creative Village Semanggi uses fishbone diagram analysis. Through fishbone diagrams, it can be determined the stages of identification as well as determining strategies for how to develop a creative village in a sustainable manner. Several parties whose cooperation is needed are: 1. City Government as Policy Maker; 2. Relevant agencies, Public Work agency, Public Service agency, BLUD Griya Surakarta, City Spatial Planning Service (DTRK), Cooperative (Koperasi) and SME (UMKM) Service-Surakarta, Surakarta Culture and Tourism Office, and the public order officer Unit (Pamong Praja); 3. Chairman of the Association of Semanggi area as the leader who will coordinate the entire community; and 4. Mass Media to help in socialization and communication media. (Arlis 
Hardiyanto, Ayu Edhi Sri Wulansari \& Muhammad Farizan Praevia, Zakariya Arif Fikriyadi, 2015)

Meanwhile, from the Central Government there has been PMK3I (Independent Assessment of Indonesian Creative City) which is a program designed by the Deputy for Infrastructure of the Creative Economy Agency (Bekraf) with the aim of embracing all stakeholders or ABCG (Academician, Business, Community and Government) actors from to 16 sub-sectors in all regencies and cities throughout Indonesia. The task of PMK3I is to identify the characteristics and recommend the superior sub-sectors of the respective regions that are part of the national creative economy ecosystem. The PMK3I program uses websites and applications as a communication infrastructure that can be used independently by Indonesian creative actors wherever they are. On the website, there are guidelines, forms and various information needed with facilitation from the Directorate of Physical Infrastructure Facilitation and the PMK3I Team and the support of PMK3I Assessors who are appointed every year. (Sobandi et al., 2018)

This is in accordance with current update technological developments that have reached whole society, especially the use of Big Data technology which is currently still being developed. It is an opportunity as well as a challenge for the government to innovate the integration of public services to the community by utilizing Big Data technology. (Islah, $\underline{2018)}$

The use of this technology will support the progress of society in various fields, including in realizing this Creative Village (kelurahan kreatif) towards to realize a Creative City (Sobandi et al., 2018) that having one or more subsector of creative economy that become a backbone of economic for the society. Also, to support the activation of required ecosystem with four actors: Academic, Business, Community and Government, that supported by media.

\section{CONCLUSION}

Based on the results of the study and the discussion, it can be concluded that to realize the Creative City can be started from the formation of Kelurahan Kreatif or Creative Village as a form of support and to encourage civil society from the young, namely Karang Taruna. This certainly needs support from various parties, both government, society, and the private sectors for the realization of the creative economy in the community that will be the backbone of the economy, while improving the environment in society.

\section{REFERENCE}

Adnan, M. N., Safeer, R., \& Rashid, A. (2018). Consumption based approach of carbon footprint analysis in urban slum and non-slum areas of Rawalpindi. Habitat International, 73, 16-24. https://doi.org/10.1016/j.habitatint.2017.12.012

Alam, F. C., Sembiring, E., Muntalif, B., \& Suendo, V. (2019). Microplastic distribution in surface water and sediment river around slum and industrial area (case study: Ciwalengke River, Majalaya district, Indonesia). Chemosphere, 6(1), 19. https://doi.org/https://doi.org/10.1016/j.chemosphere.2019.02.188

Arlis Hardiyanto, Ayu Edhi Sri Wulansari, R. R. P., \& Muhammad Farizan Praevia, Zakariya Arif Fikriyadi, I. (2015). Kampung Kreatif Semanggi: Penataan Kelurahan Semanggi, Surakarta Berbasis Kelokalan dan Wisata Edukasi Kreatif dengan Optimasi Potensi Koridortanggul dan Rel Kereta Api. Simposium Nasional RAPI XIV, 1, 27-34.

Aziz, S., Pakhtigian, E. L., Akanda, A. S., Jutla, A., Huq, A., Alam, M., Ashan, G. U., \& Colwell, R. R. (2021). Does improved risk information increase the value of cholera prevention? An 
analysis of stated vaccine demand in slum areas of urban Bangladesh. Social Science \& Medicine, 272, 113716. https://doi.org/10.1016/j.socscimed.2021.113716

Aziz, T. A., \& Shawket, I. M. (2011). New strategy of upgrading slum areas in developing countries using vernacular trends to achieve a sustainable housing development. Energy Procedia, 6, 228-235. https://doi.org/10.1016/j.egypro.2011.05.026

Das, M., Das, A., Giri, B., Sarkar, R., \& Saha, S. (2021). Habitat vulnerability in slum areas of India - What we learnt from COVID-19? International Journal of Disaster Risk Reduction, 65, 102553. https://doi.org/10.1016/j.ijdrr.2021.102553

Islah, K. (2018). PELUANG DAN TANTANGAN PEMANFAATAN TEKNOLOGI BIG DATA UNTUK MENGINTEGRASIKAN PELAYANAN PUBLIK PEMERINTAH. Reformasi Administrasi.

Izutsu, T., Tsutsumi, A., Islam, A. M., Kato, S., Wakai, S., \& Kurita, H. (2006). Mental health, quality of life, and nutritional status of adolescents in Dhaka, Bangladesh: Comparison between an urban slum and a non-slum area. Social Science \& Medicine, 63(6), 1477-1488. https://doi.org/10.1016/j.socscimed.2006.04.013

Khalifa, M. A. (2011). Redefining slums in Egypt: Unplanned versus unsafe areas. Habitat International, 35(1), 40-49. https://doi.org/10.1016/j.habitatint.2010.03.004

Klein, T., \& Anderegg, W. R. L. (2021). A vast increase in heat exposure in the 21 st century is driven by global warming and urban population growth. Sustainable Cities and Society, 73, 103098. https://doi.org/10.1016/j.scs.2021.103098

Michiani, M. V., \& Asano, J. (2019). Physical upgrading plan for slum riverside settlement in traditional area: A case study in Kuin Utara, Banjarmasin, Indonesia. Frontiers of Architectural Research, 8(3), 378-395. https://doi.org/10.1016/j.foar.2019.03.005

Murray-Tortarolo, G. N., \& Jaramillo, V. J. (2020). Precipitation extremes in recent decades impact cattle populations at the global and national scales. Science of The Total Environment, 736, 139557. https://doi.org/10.1016/j.scitotenv.2020.139557

Nyenje, P. M., Havik, J. C. N., Foppen, J. W., Muwanga, A., \& Kulabako, R. (2014). Understanding the fate of sanitation-related nutrients in a shallow sandy aquifer below an urban slum area. Journal of Contaminant Hydrology, 164, 259-274. https://doi.org/10.1016/j.jconhyd.2014.06.011

Rivera-Padilla, A. (2021). Slums, allocation of talent, and barriers to urbanization. European Economic Review, 140, 103908. https://doi.org/10.1016/j.euroecorev.2021.103908

Sobandi, R., Sasongko, A., Harijadi, D. A., Abdullah, L. A., Tyaghita, B., Toriq, A., \& Editor. (2018). Kata Kreatif. In Badan Ekonomi Kreatif.

Sugianti, D. H., \& Ekomadyo, A. S. (2016). Strategi Kampung Kreatif sebagai Upaya Perbaikan Lingkungan Kota menurut Kerangka Pemenuhan Kebutuhan Manusia (Studi Kasus: Kampung Jambangan). Prosiding Temu Imiah IPLBI, 119-126.

Sugiyono. (2017). Metode Penelitian Kuantitatif Kualitatif dan R\&D. Alfabeta.

Wardhani, S. T., Sabatini, S. N., Rachmaniatus, D., \& Kasman, T. M. S. (2016). Identifikasi Kampung Kreatif sebagai Strategi Kota Tangguh. Prosiding Temu Ilmiah IPLBI, 15-20.

Yang, X., Li, N., Mu, H., Zhang, M., Pang, J., \& Ahmad, M. (2021). Study on the long-term and short-term effects of globalization and population aging on ecological footprint in OECD countries. Ecological Complexity, 47, 100946. https://doi.org/10.1016/j.ecocom.2021.100946 